\title{
Risk of diseases transmitted by Aedes mosquitoes in the Metropolitan Area of the Valley of Mexico and the threat of syndemics in the country
}

\section{Riesgo de enfermedades transmitidas por mosquitos Aedes en la zona metropolitana del Valle de México y amenaza de sindemias en el país}

\author{
José A. Díaz-Quiñonez* \\ Postgraduate Education Division, Faculty of Medicine, Universidad Nacional Autónoma de México, Mexico City, Mexico
}

$\ldots$ and because as long as Aëdes aegypty is not eliminated from the root in America, there may be excessively costly urban epidemic outbreaks that should be avoided by eradication of the domestic vector in America... Miguel E. Bustamante

In the preliminary note of his 1964 book Breve historia y antología sobre la fiebre amarilla (Brief history and anthology of yellow fever), the poet, essayist and playwright Salvador Novo wrote:

On August 6, 1963, Dr. José Álvarez Amézquita, Secretary of Health and Assistance of Mexico, presented Dr. Luther Terry, Surgeon General, Public Health Service, USA Department of Health, with a unique gift: inside a small plastic cube, he handed him the last couple -female and male- of Aedes aegypti captured in our territory.

That symbolic event represented the apotheosis of a long-standing struggle to eliminate the urban yellow fever vector from our country (and from the Mesoamerica described by Miguel E. Bustamante). Thus concluded a prolonged campaign led by federal and state health authorities, supported by scientists and public health professionals. A health program that facilitated the legitimate right to social participation, through huge community work.

In an exchange of letters, Secretary Álvarez Amézquita thanked the also historian and chronicler, who was member of the Contemporáneos group:2

It is also relevant and worthy of my recognition, the dissemination that through Historia y Antología de la Fiebre Amarilla will be made in Mexico about that public health problem that for more than 400 years was a shadow in the conscience of the men responsible in the fight for a Mexico free of the greatest evils.

On September 1963, during the plenary session of the $14^{\text {th }}$ Meeting of the Pan American Health Organization Board of Directors and $15^{\text {th }}$ of the World Health Organization Regional Committee, resolution CD14. R13 was approved, which concluded "we accept the report presented by Mexico, congratulate said country for the works it has carried out, and for having declared its territory free of Aedes aegypti". On his fifth governance report, President Adolfo López Mateos informed the nation about the eradication of the disease that for centuries, through the mosquito as vector, kept the ports and coastal cities of the country at constant health risk. ${ }^{3}$

Nevertheless, this is already part of our history, the history of Mexican literature and public health.

In 1979, the first dengue fever epidemic was reported in Mexico after the reintroduction Aedes aegypti, which is considered the primary vector associated with the transmission of all four serotypes of the virus, while Aedes albopictus, which is less efficient, is considered the secondary vector. Mosquitoes that transmit other diseases such as Zika fever, West Nile fever, various types of encephalitis, chikungunya epidemic arthritis and Mayaro fever, in addition to yellow fever, belong to the Aedes genus.

Aedes is native to Africa, but currently it is found in tropical and subtropical regions of the planet. Its expansion to different territories has been associated
Correspondence:

*José A. Díaz-Quiñonez

E-mail: adiazq@unam.mx
Gac Med Mex. 2020;156:363-365 Contents available at PubMed

www.gacetamedicademexico.com

0016-3813/@ 2020 Academia Nacional de Medicina de México, A.C.. Published by Permanyer. This is an open access article under the CC BY-NC-ND license (http://creativecommons.org/licenses/by-nc-nd/4.0/). 
with massive human migrations. ${ }^{4}$ Initially, the mosquito arrived to America with African slave trade between the $15^{\text {th }}$ and $19^{\text {th }}$ centuries, and then it spread throug Asia as a result of trade during the $18^{\text {th }}$ and $19^{\text {th }}$ centuries. Worldwide redistribution of the mosquito occurred after World War II, with the mobilization of troops.

Over the past 50 years, Aedes-borne diseases have emerged or reemerged throughout the world. ${ }^{5}$ The dengue virus continues to increase, causing approximately 390 million human infections per year; the chikungunya virus has spread all over the world since the early 2000s; the Zika virus has also spread over the last five years, and yellow fever has recently reemerged in Africa and South America. ${ }^{6}$ The spread of these diseases is explained by the presence of conditions that favor Aedes spread and proliferation as a result of global trade, population growth, unplanned urbanization, inefficient vector control, water supply and waste management programs implementation, as well as a lack of political will and community commitment. ${ }^{7}$ All the viruses that cause these diseases are mainly transmitted by Aedes aegypti and, to a lesser extent, by Aedes albopictus. The global economic impact of diseases transmitted by these vectors is not yet known, ${ }^{8}$ but economic losses due to dengue are estimated to be at least USD 9 billion annually. ${ }^{9}$

In this 2020 Gaceta Médica de México number 5 issue, two articles review the emergence of $\mathrm{Ae}$ des-borne diseases. In one, the risk represented by the establishment of the Aedes aegypti mosquito in the metropolitan area of the Valley of Mexico and the diseases it can transmit in a population of approximately 22 million people is analyzed. The other one evaluates the possibility of a syndemic between COVID-19 and Dengue fever in southeastern Mexico, which is not the only region of the country at risk: the first death was recorded in El Salto, Jalisco.

In recent years, entomological surveillance carried out by the Vector-Borne Diseases Program has confirmed the spread of Aedes aegypti and its presence in territorial demarcations of Mexico City ${ }^{10}$ and surrounding municipalities, which has demonstrated that the presence of the vector is not circumscribed to a particular altitude and temperature. ${ }^{11}$

In their review, Mejía-Guevara et al. report the constant and increasing identification of the vector over the last five years in the metropolitan area of the Valley of Mexico, which shows the establishment of the mosquito in territorial demarcations Azcapotzalco, Coyoacán, Gustavo A. Madero, Iztacalco, Venustiano
Carranza and Xochimilco (north, northeast, south and center of Mexico City), ${ }^{12}$ as well as in neighboring suburbs Los Reyes, La Paz and Nezahualcóyotl, in the State of Mexico. Timely entomovirological surveillance carried out by the "Manuel Martínez Báez" Institute for Epidemiological Diagnosis and Reference has confirmed the worrying presence of mosquitoes infected by dengue and Zika viruses in some specimens collected in Mexico City. ${ }^{13}$ Aedes aegypti and albopictus mosquitoes reproduction is difficult to control once populations have been established. It only takes an increase in vector density, sufficient geographic colonization, and an adequate number of infected patients for outbreaks to occur (a situation that already occurs in municipalities of the States of Mexico and Morelos lower areas).

Given the possibility of epidemics of diseases transmitted by this vector, it is urgent to communicate the general population about the risk, as well as to train health professionals for the identification of suspected and probable cases of arboviroses transmitted by $\mathrm{Ae}$ des in the metropolitan area of the Valley of Mexico. It would be desirable for the National Epidemiological Surveillance System to establish routine detection of other vector species and other arboviruses of public health importance (Saint Louis encephalitis virus, Venezuelan equine encephalitis virus, Eastern equine encephalitis virus, Western equine encephalitis virus, yellow fever virus, Mayaro virus, dengue virus, West Nile virus, Zika virus). Before the spread of vectors becomes more extended, an intense vector control campaign is required in order to protect individuals who are immunologically susceptible to primary infections by arboviruses.

The term syndemic, recently introduced by medical anthropologists, refers to the interaction of two or more coexisting epidemics and the resulting disease burden excess. ${ }^{14}$ The term is applied to synergistic health problems that affect the health of a population at its social and economic contexts, which require the creation of specific conceptual frameworks to identify risk factors, in order to implement prevention and control programs for addressing comorbidities. ${ }^{15}$

The syndemic between COVID-19 and dengue fever in the southeast of the country is addressed by Sánchez-de la Cruz et al. ${ }^{16}$ The authors identify this syndemic as a threat that can collapse health systems in states of the southeast and Pacific coast. These simultaneous epidemics complicate the epidemiological landscape, as well as timely diagnosis, control, and treatment..$^{17}$ In Mexico, by 2020 epidemiological week 
$38,11,228$ cases of dengue with 28 deaths had been reported..$^{18}$ Cases of co-infection with dengue virus and SARS-CoV-2 have already been reported at different states, one of them with a fatal outcome in Jalisco. ${ }^{19}$ This co-infection scenario not only applies to dengue, influenza and other diseases with a seasonal component, but also to the diabetes and obesity epidemics. The bad news is that this epidemiological reality will remain as long as the COVID-19 pandemic persists.

Unless a coordinated and preventive approach to control the mosquito is adopted, outbreaks of vector-borne diseases will be increasingly common and will generate new syndromes in the country (by coinciding with the metabolic syndromes epidemic and the pandemic caused by SARS-CoV-2 virus). Improving our surroundings -through a culture of sanitary fostering and health promotion- will contribute to a longterm solution in order to reduce health risks and the emergence of epidemic diseases.

\section{References}

1. Bustamante ME. La fiebre amarilla en México y su origen en América Mexico: Secretaría de Salubridad y Asistencia, Instituto de Salubridad y Enfermedades Tropicales; 1958.

2. Novo S. Breve historia y antología sobre la fiebre amarilla. Mexico: Secretaría de Salubridad y Asistencia/Prensa Médica Mexicana; 1964.

3. Informes Presidenciales. Adolfo López Mateos. V Informe de Gobierno. Mexico: Servicio de Investigación y Análisis/Subdirección de Referencia Especializada; 2006

4. Sherpa S, Rioux D, Goindin D, Fouque F, François O, Després L. At the origin of a worldwide invasion: unraveling the genetic makeup of the Caribbean bridgehead populations of the dengue vector Aedes aegypti. Genome Biol Evol. 2018;10:56-71.
5. Roiz D, Wilson AL, Scott TW, Fonseca DM, Jourdain F, Müller P, et al. Integrated Aedes management for the control of Aedes-borne diseases. PLoS Negl Trop DIS. 2018;12:e0006845.

6. Wilder-Smith A, Gubler DJ, Weaver SC, Monath TP, Heymann DL, Scott TW. Epidemic arboviral diseases: priorities for research and public health. Lancet Infect Dis. 2017;17:e101-e106.

7. Lindsay SW, Wilson A, Golding N, Scott TW, Takken W. Improving the built environment in urban areas to control Aedes aegypti-borne diseases. Bull World Health Organ. 2017;95:607-608.

8. Bradshaw CJ, Leroy B, Bellard C, Roiz D, Albert C, Fournier A, et al. Massive yet grossly underestimated global costs of invasive insects. Nature Communications. 2016;7:12986.

9. Shepard DS, Undurraga EA, Halasa YA, Stanaway JD. The global economic burden of dengue: a systematic analysis. Lancet. Infect Dis. 2016;16:935-941.

10. Kuri-Morales P, Correa-Morales F, González-Acosta C, Sánchez-Tejeda G, Dávalos-Becerril E, Juárez-Franco MF, et al. First report of Stegomyia aegypti (Aedes aegypti) in Mexico City, Mexico. Med Vet Entomol. 2017;31:240-242.

11. Yáñez-Arenas $C$, Rioja-Nieto $R$, Martín GA, Dzul-Manzanilla F, Chiappa-Carrara X, Buenfil-Ávila A, et al. Characterizing environmental suitability of Aedes albopictus (Diptera: Culicidae) in Mexico based on regional and global niche models. J Med Entomol. 2018:55:69-77.

12. Mejía-Guevara MD, Correa-Morales F, González-Acosta C, Dávalos-Becerril E, Peralta-Rodríguez JL, Martínez-Gaona A, et al. El mosquito del dengue Aedes aegypti en la Ciudad de México. Invasión incipiente y sus potenciales riesgos. Gac Med Mex. 2020;156:

13. Dávalos-Becerril E, Correa-Morales F, González-Acosta C, Santos-Luna R, Peralta-Rodríguez J, Pérez-Rentería C, et al. Urban and semi-urban mosquitoes of Mexico City: a risk for endemic mosquito-borne disease transmission. PLoS One. 2019;14:e0212987.

14. Singer M, Clair S. Syndemics and public health: reconceptualizing disease in bio-social context. Med Anthropol Q. 2003;17:423-441.

15. Singer, M. Introduction to syndemics: a critical systems approach to public and community health. USA: Jossey-Bass; 2019.

16. Sánchez-de la Cruz JP, Tovilla-Zárate CA, González-Morales DL, González-Castro TB. Riesgo de sindemia entre COVID-19 y fiebre del dengue en el sur de México. Gac Med Mex. 2020;156:

17. Nacher M, Dorine M, Gailes M, Flamed C, Rosset D, Rousseau C, et al. Simultaneous dengue and COVID-19 epidemics: Difficult days ahead? PLoS Negl Trop Dis. 2020 Aug 14;14(8):e0008426. DOI: 10.1371/journal. pntd.0008426. eCollection 2020)

18. Secretaría de Salud [Internet]. México: Panorama Epidemiológico de Dengue. Semana epidemiológica 38, 2020. Available at: https://www. gob.mx/cms/uploads/attachment/file/579762/Pano dengue 38 2020.pdf

19. Secretaría de Salud de Jalisco [Internet]. Identifica SSJ primeros casos de COVID-19 y dengue en Jalisco. Available at: https://ssj.jalisco.gob. $\mathrm{mx} /$ prensa/noticia/9229 